\section{RECORD OF ABUDEFDUF SORDIDUS (FORSKAL) (POMACENTRIDAE: PISCES) FROM KOTTAPUZHA ESTUARY, KERALA, WITH A NOTE ON THE ECOLOGICAL ATTRIBUTES OF THE ESTUARY}

\author{
K.C. Gopi and Mohammed Jafer Palot
}

Western Ghats Field Research Station, Zoological Survey of India, Kozhikode, Kerala 673002, India.

The members of the genus Abudefduf (=Glyphidodon, Glyphisodon) - Sergeant majors - of sub-family Pomacentrinae (Fam: Pomacentridae) are primarily tropical marine fishes, generally found along coastal areas of tropical and temperate regions of the world. Their main habitat in the marine ecosystem is rocky pools or coral reefs. These fishes are lively and strongly territorial, subsisting mainly on algae and small invertebrates.

Abudefduf sordidus (Forskal), commonly called the 'Greybanded Sergeant Major', is a small to moderate-sized species, known to be an exclusive marine dweller, very common and widely distributed in Indo-Pacific Oceans including the Red Sea and Hawaii. Its main habitat being rocky pools and reefs, this species is seldom known to make forays to estuarine brackish waters in the coastline areas. Day (1875-1878) has recorded this species - as Glyphidodon sordidus (Forskal) from the Sind (Pakistan) coasts of Indian Ocean, indicating its wide distribution, but nothing as regards its estuarine visitations.

As part of the faunal explorations of the mangrove ecosystem associated with the Kottapuzha estuary at Kolavipalam in Kozhikode District, Kerala, one specimen of A. sordidus (Forskal) was obtained, on 5 October 2001, from the mangrovelined bay waters. The specimen, $14.5 \mathrm{~cm}$ long (Fig. 1), was collected by a fisherman in his cast net, while fishing at an interior site in the estuary bay, about $0.5 \mathrm{~km}$ away from the coast-line waters. The local community fishermen remarked that the incidence of this fish species entering the estuarine waters has never been observed earlier, though the specimens of the same or resembling types are known to frequent the rocky-reef environs found along coastal waters and, occasionally, caught during fishing operations. The collection of $A$. sordidus (Forskal) from the mangrove-lined estuary bay is, therefore, reported here since no such information is so far known pertaining to its foraging visits to estuarine waters in

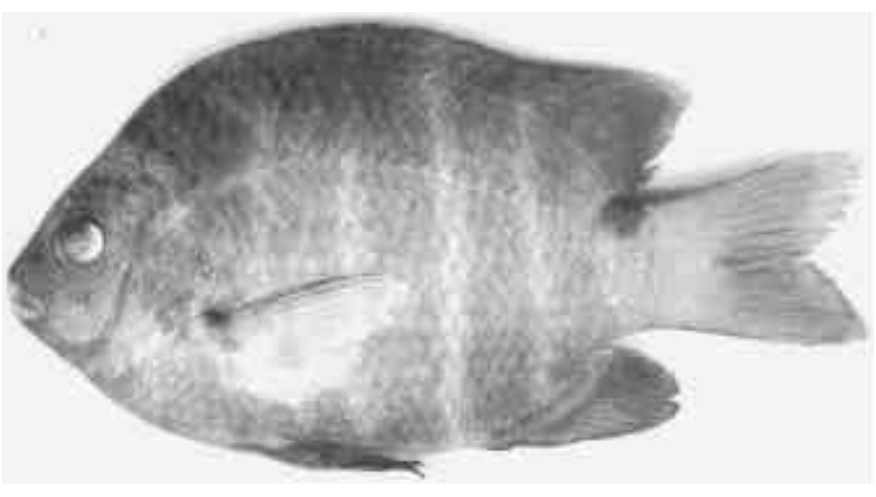

Fig. 1. Grey-banded Sergeant Major, Abudefduf sordidus (Forskal)

any part of the considerable stretches of estuarine/brackish water-zones found along the coasts of Kerala.

The genus Abudefduf, as in other genera of the family Pomacentridae, exhibits considerable morphological diversity, including colour patterns, often varying with individuals and between habitats, among its species, exemplifying species complexes (Nelson, 1994). Carcasson (1977) has listed as many as 48 species under the genus, about 39 of them being illustrated as better known members often used as fish curios in the marine aquariums. Nelson (1994) has, however, noted a diversity of only 18 species following Allen (1991).

The specimen collected from the Kottapuzha Estuary has been identified as A. sordidus (Forskal) by the following characteristics:

Body: Deep, orbiculate and compressed; head with single nostril on each side; mouth small; subocular shelf present, pre-orbital edge without a notch; single continuous dorsal fin with 13 spines and 15 softrays; anal fin with two spines and 14 softrays; soft dorsal and anal fins similar; caudal fin forked; scales large (smaller on head), ctenoid; bases of unpaired fins scaled; lateral line incomplete, with 23 (perforated) +7 scales; scale-rows in transverse series $4 / 1 / 12$.

Colours: Olive-green-yellow body with five vertical, dull-grey bands on sides; a black spot at the base of pectoral, a row of black spots across the nape; a black spot/blotch on the caudal peduncle right behind the dorsal. This peduncular black spot which is not mentioned by Day (1875-1878), readily distinguishes this species from its congeners (Axelrod \& Emmens, 1969; Burgess et al., 1990).

Coral and rocky reef environs in the waters around the Lakshwadeep Islands - a Union Territory of India located about $220 \mathrm{~km}$ off the coast of Kerala, in the Arabian Sea (Indian Ocean) 
- are reported to harbour about 12 species of Abudefduf, including A. sordidus (Anon, 1998). Atleast six of them (A. bengalensis (Bloch), A. cingulum (Kluzinger), A. saxatilis (Linn.), A. septemfasciatus C. \& Val., A. sordidus (Forskal) and A. zonatus (C. \& Val.) are known to occur in the coastal waters of Kerala as revealed in the exploratory marine resource surveys conducted by the Central Marine Research Institute, Cochin (pers. comm.). But none of these species have been reported as being a visitor to the estuarine/brackish water zones of the state.

The mangrove-lined estuary bay from which the fish $A$. sordidus was collected, forms the southward extension of the estuary, from the river mouth. It lies parallel to the coastline waters, separated from it by the sandy bed of the Kolvaipalam Beach, a prime nesting site of Olive Ridley Turtles in the Kerala coast. A notable feature of the estuary bay is that it is devoid of rocky reef environs, the homely habitat of the fish species collected. But, the other side of the river mouth, sandwiched between the northward extension of estuary and the coastline waters, is a beach resort, with its sea-facing front being replete with rockyreefs jutting into the sea. Thus, the interface zone constituting the Kottapuzha Estuary and the coastline waters into which the estuary opens, is having both the habitat characteristics of the marine-reef environs as well as the sandy, marsh-alluvium environs of the mangrove ecosystem. The tendency of the fish to leave its reef habitat environs in the shore waters and make its forays to the estuarine habitat is possibly due to the juxtaposition of these two habitat environs. Thus the Kottapuzha estuary zone including its mangrove-lined estuary bay becomes an ideal foraging and breeding ground for a wide variety of both marine and estuarine fishes and other faunal communities.

The occurrence of a localized 'mud banking' phenomenon popularly called 'Chakara' with the localized appearance of marine organisms in abundance, during monsoon, along the Kerala coast - in and around the coastal waters of Kottapuzha estuary and Kolavipalam areas, for a short duration, coinciding with the period of collection of this species, also might have been a reason for attracting the fish A. sordidus to the shore waters of the Kolavipalam and also to the estuarine waters, particularly during high tide, for the purpose of foraging.

\section{Acknowledgement}

Authors are grateful to the Director, Zoological Survey of India, Kolkata, and the Officer-in-Charge, Western Ghats Field Research Station, Zoological Survey of India, Kozhikode, for encouragement and facilities. We are indebted to Dr. K.K. Philipose, Scientist, Central Marine Fisheries Research Institute - (ICAR), Kozhikode for the help and for providing requisite literature. Our sincere thanks are also due to Dr. K. Rama Devi, Scientist 'C', Southern Regional Station, Zoological Survey of India, Chennai, for kindly reviewing the manuscript.

\section{References}

Allen, G.R. (1991). Damsel Fishes of the World. Mergus, Melle, Germany, 271pp.

Anon, (1998). Training course on ornamental fish culture, a manual. Central Marine Fisheries Research Institute - (ICAR), Cochin.

Axelrod, H.R. and C.W. Emmens (1969). Exotic Marine Fishes. T.F.H. Publications, Neptune City, USA, 607pp.

Burgess, W.E., H.R. Axelrod and R.E. Hunziker (1990). Dr. Burgess's Atlas of Marine Aquarium Fishes. T.F.H. Publications, Neptune City, USA, 768pp.

Carcasson, R.H. (1977). Coral Reef Fishes of the Indian and West Pacific Oceans. William Collins Sons \& Co. Ltd., Glassgow, U.K., 320pp.

Day, F. (1875-1878). The Fishes of India: A Natural History of the Fishes known to Inhabit the Seas and Freshwaters of India, Burma and Ceylon. Text and atlas in 4 parts. London, $\mathrm{xx}+778 \mathrm{pp}, 195 \mathrm{pls}$.

Nelson, J.S. (1994). Fishes of the World. John Wiley and Sons, New York, xvii+599pp. 